Pakistan Journal of Humanities and Social Sciences

October - December 2018, Volume 6, No. 4, Pages 493 - 515

\title{
Does Trade Liberalization Affect Energy Saving in Nigeria?
}

\author{
Aliyu Alhaji Jibrilla ${ }^{1}$ \\ ${ }^{1}$ Department of Economics, Faculty of Social and Management Sciences, Adamawa State \\ University, P.M.B 25 Mubi, Adamawa State, Nigeria \\ Email: aliyumaiha@gmail.com
}

\begin{abstract}
The study empirically examines the role of trade openness and other determinants in explaining the intensity of energy use in Nigeria using annual data from 1981 to 2015. The paper uses an auto-regressive distributed lag (ARDL) model in interpreting both long-run energy intensity as a co integrating relation, and its short-run dynamics. The robustness of ARDL results is verified using Dynamic OLS (DOLS) estimation technique. The results provide evidence of a Cointegration relation between energy intensity and its determinants. The results provide evidence that trade only significantly reduces energy intensity in the short run. Meanwhile, the results also show that income growth and industry value added have significant reducing effects on energy intensity. The results also raise some important policy issues, particularly on the inflows of foreign aid.
\end{abstract}

Keywords: Trade Openness; Energy intensity, ARDL

JEL Classification Codes: $\quad$ C01; F14; F41; N7; Q43

\section{Introduction}

Nigeria is the most populated country in the African continent with over 190 million people (World Bank, 2017). More than half of this population lives in the rural areas (Reed \& Mberu, 2014), most of whom live on less than two US dollars a day (ADB, 2018). One way to deal with poverty is to promote opportunity such as access to modern energy services (World Bank, 2001; Kanagawa \& Nakata, 2008). Increasing access to modern energy such as electricity will considerably improve the quality of life of those who particularly do not have access to it yet. It is important to note that, access to modern energy services is not spread equally across rural and urban areas. People living in the rural areas depend largely on burning traditional biomass such as wood and agricultural residues (which are known to cause pollution to the environment) to meet their energy needs and that there are about 80 million Nigerians who do not have access to electricity, greatest of them are in rural areas. It is 
estimated that only some 41.1 percent of the rural population have access to electricity in Nigeria, while about 86 percent of urban people have energy access (Trading Economics, 2018). The lack of energy access (also known as 'energy poverty') is linked to general poverty (Cecelski, 2003; Kanagawa, M., \& Nakata, 2008; Kaygusuz, 2011), and can, therefore, cause adverse effects on the socioeconomic condition of the people affected. Consequently, improving energy access will have enormous impacts on people's lives in rural areas as well as well as those in the urban areas who do not have access yet.

Improving energy access to Nigerians is, therefore, critical to improve their economic condition in particular and to realize the sustainable development goals of the country in general. The benefit of making the supply of modern energy services adequate for the country is the opportunity it offers to increase production efficiency, income growth, and employment as well as to promote effective public services such as education and health care (see Mernier, 2012). Further, the Advisory Group on Energy and Climate Change (2010) called on countries to ensure that access to reliable, affordable, and sustainable modern energy services and where possible, prioritize ensuring access to low-pollution-emitting energy sources. This position, therefore, represents future calls for energy conservation or stimulating innovation in the energy-saving technologies.

In principle, variations in a nation's energy use are usually explained in terms of structural factors (composition of national output and technological factors (energy efficiency improvement (Welsch \& Ochsen, 2005). It is not uncommon that factors such as replacing old technology with new ones and/or improvement in energy management can reduce the energy intensity of a nation's industrial processes. It is also suggested in the energy literature that, increasing global economic integration through trade liberalization can have a positive effect on energy efficiency, which is indeed possible through spill-over of energy-saving technologies (Lermit \& Jollands, 2001; Saggi, 2002; Welsch \& Ochsen, 2005; Lescaroux, 2008; Ang, 2009; Hübler \& Keller, 2010). Could this imply that trade openness can effectively help to reduce energy intensity (and possible environmental problems that may be associated with higher energy consumption)? Responding to this question requires at least information on the relationships between energy intensity and trade liberalization.

Nigeria as a relatively open and growing economy signifies an ideal country to empirically evaluate whether trade openness alongside other structural determinants has a significant effect on energy intensities. Besides, since 1986 Nigeria has embarked on Liberalizing foreign trade as part of the IMF- World Bank economic policy embodied in 
Structural Adjustment Programme (SAP). One of the main policy thrust of SAP was to robustly promote the development of the industrial sector and accelerate export diversification (See Anyanwu, 1992; Chete, Adeoti, Adeyinka \& Ogundele, 2014).

Indeed, industrialization should be considered desirable to enable the country to diversify its export base, but such a strategy can also have a negative and substantial environmental impact. For example, being a country with a limited technical capacity (see, for example, Oyedepo, 2012), there is no guarantee that industrialization will ensure economic progress that does not compromise environmental quality, since technology holds the key to raising economic productivity and minimizing environment impact (see, for example, Jung, Krutilla \& Boyd, 1996; Helpman \& Rangel, 1999; Kneller, 2005; Hübler \& Keller, 2010 among others). Energy studies have identified that Nigeria is reasonably endowed with a number clean and renewable energy sources, but the current situation of energy management in the country is rather less impressive (see, for example, Oyedepo, 2012; Maji, 2015).

Although, studies have indicated that, Nigeria has a potential for industrial energyefficiency improvement in a cost-effective manner, the country is yet to fully identify the energy conservation measures necessary to attain the desired results (Aiyedun \& Adeyemi, 2008; Jekayinfa \& Bamgboye, 2008; Aderemi, Ilori, Aderemi \& Akinbami, 2009; Gosh we, \& Kureve, 2012; Olayinka \& Oladele, 2013). In this circumstance, there is a need for a research that clearly identifies most relevant factors for energy efficiency policies. This can better inform policymakers to choose appropriate intervention measures in their policy decisions. The central concern is, what are the determinants of energy intensity in the Nigerian economy, and has trade intensity had any effect on energy use? To address these questions the present study examines whether openness to international trade beside other structural factors has the potential to significantly improve energy efficiency in Nigeria.

Notwithstanding the widely acknowledged potential effect of trade liberalization on energy use, empirical work on this issue, remains, however, particularly scarce (see, for example, Antweiler, Copeland \& Taylor, 2001; Cole \& Elliott, 2003, Cole, 2006, among others). Having observed this shortfall, Cole (2006) estimated this effect using a panel data approach. Although, the author employed fixed effect estimator in his analysis to control for unobserved country-specific effect, estimates derived from the fixed effect model can only be reliable from a policy perspective, if trade policies and other factors that determine energy use are time-invariant across countries and the marginal response of energy intensity to each 
measure of trade intensity is also uniform (see also Hsiao, 2003; Plümper \& Troeger, 2007; Allison, 2009). Else, a time-series study is required to reveal more evidence on the determinants of a country's energy intensity from the perspective of energy policy.

This study, therefore, extends this body of research by empirically examining the relationship between trade openness and energy intensity in Nigeria, an issue that has largely been ignored within the country's literature. An exception was a study by Adom (2015) who reported that trade openness reduces energy intensity in Nigeria. However, the study appears limited because as it fails to take into account the effect of changes in the techniques of production due to openness to trade. If trade liberalization affects economic growth, then it may be hard to evaluate the long-run effects of trade without taking into account the effects of changes in income on energy intensity. In this context, the increase in income level represents an indirect technique effect of trade liberalization that may impact on the intensity of energy use (see also Grossman \& Krueger, 1995; Wing, 2008).

Also, Keho (2016) studied the influence of imports on energy intensity in Nigeria. Evidence from the study indicates that the effect of imports does not show up in the long run, but only in the short run: imports are found to increase energy use. However, the study may suffer from misspecification bias as no single diagnostic evaluation test result is reported alongside the empirical findings. It is a common knowledge among applied econometricians that failure of a researcher to rigorously evaluate the underlying assumptions of the regression model being considered often lead to erroneous conclusions, and of course, wrong policy prescriptions. Further, it is well-established in the energy economics literature that industry value added and foreign aid are important determinants of energy use (see, for example, Hübler \& Keller, 2010; Mosley, Hudson \& Horrell, 1987). Controlling for these variables, given their potential effects might have a performance-enhancing effect on the Nigerian energy intensity model. Consequently, aims to reveal in more detail the determinants of energy conservation in the country.

The study also accounts for the potential problems associated with a fixed effect model, the endogeneity issues (see, for example, Kose, Prasad \& Terrones, 2006). Including trade intensity as a determinant of energy use helps policy makers' understand its possible effects on energy intensity and sustainable energy efficiency in the long run. Moreover, the results of this study will justify the need for additional effort to improve trade policymaking in the country, particularly with regard to inflows of energy-saving technologies. 
Pakistan Journal of Humanities and Social Sciences, 6(4), 2018

The remaining part of this study is structured as follows: Section 2 presents a review of the literature. Section 3 describes models, data and methodology. Section 4 reports the empirical results and, finally, section 5 presents conclusions and policy implications.

\section{Literature review}

The view that liberalization has a potential effect on energy efficiency is an issue that has recently been receiving a growing number of theoretical researches. One of the common practices by researchers in the trade and environment literature, which is used as the chief theoretical foundation for the present study, is to decompose the effects of economic growth through trade openness on the environment into scale effect; composition effect and technique effect (see Grossman \& Krueger, 1993; Antweiler et al., 2001; Cole \& Elliott, 2003; Frankel, 2009). Cole (2006) has argued that since energy consumption is one of the major determinants of greenhouse gases, this framework is also applicable to energy use (see also Hübler \& Keller, 2010).

The Scale effect represents changes in energy demand due to increased economic activity and/or output resulting from the trade intensity (Antweiler et al., 2001; Cole, 2006). For example, since more openness to trade tends to promote higher economic growth, which may, in turn, be associated with higher energy demand, can indirectly have a positive effect on energy use. This effect may, however, depend on the level of the influence of trade intensity on economic growth.

The composition effect signifies changes in the production structure of an economy as a result of increasing openness to international trade. The effect of this structural change on energy intensity in the production process within the domestic economy will, for instance, hinge on the sectors in which such an economy has a comparative advantage that can be stimulated by the country's environmental standards, capital-to-labor ratio and/or changes in the industry value added (Cole, 2006; Hübler \& Keller, 2010). The composition effect will result in more energy-intensive production if the production structure of an economy is moving away from primary towards industry-based production (particularly capital-intensive ones (Fisher-Vanden, Jefferson, Liu \& Tao, 2004; Cole, 2006). However, a less energy intensity may be observed, if activity in the production process moves from (heavy) industry towards the lighter industry or service sector (see Stern, 2004; Hübler \& Keller, 2010; Jibrilla $\&$ Ismail, 2015). In the case of Nigeria, if, for example, more openness to international trade promotes more activities in extractive and heavy industries and less in the service sector or 
light industries, more trade will likely increase energy intensity since the growing sector will demand more energy inputs, and vice-versa.

The technique effect implies changes in the techniques of production due to more openness to international trade that influences energy consumption. For example, a study by the World Bank (2008) demonstrates that trade openness can considerably increase the transfer and diffusion of clean technologies in low-income countries. This finding implies, the technique effect represents the influence of trade liberalization that led to improvements in energy efficiency, so that the production process in the economy reduces energy use. Likewise, more openness to international trade increases income which can facilitate the development of environmental standards and stimulate energy saving-innovations and, hence a low intensity of energy use (see Grossman \& Krueger, 1995; Wing, 2008).

There is emergent empirical literature on energy saving spillover and transfers through trade liberalization with mixed evidence. In his survey, Saggi (2002), however, a note that trade liberalization, which alters resource allocation plays a vital role in the cross-border knowledge transfer. Among other empirical works, Eaton and Kortum (1996) find that research and development $(\mathrm{R} \& \mathrm{D})$ spillovers is more correlated with productivity growth than domestic R\&D activity. However, their study did not analyze the effect of such spillover and/or productivity increase on energy efficiency. Although recent studies have acknowledged the potentials of trade liberalization on energy efficiency, at best, this issue remains inadequately investigated. Best available evidence is the work of Cole (2006) who examined the effect of trade intensity on the energy use of a panel of 32 countries, and conclude that, such effect (of trade liberalization) can be positive or negative, depending on a country-specific comparative advantage (whether a country is an importer or exporter of energy-intensive goods. Although a study by Adom (2015) has departed from the panel analysis of this issue and considers a time series analysis with a Nigerian data, the study appears to ignore an important variable in energy modeling, the country's income level. Also, in a study by Keho (2016) imports seems to increase energy intensity in the short run, an effect that failed to be significant in the long run. However, the author did not report diagnostic evaluation test results alongside the empirical results (such as misspecification tests, autocorrelation tests, multicollinearity tests etc.). Only by rigorously evaluating the underlying assumptions of the model can one be assured of the reliability of the findings and subsequent conclusions are drawn. It is possible that some important variables are omitted from the model or that the modeling process may suffer from misspecification bias, which in 
turn may lead to the problem of autocorrelation (see Finger, 1994). It is not uncommon that omitted variable bias can cause reasonable or severe harm to regression estimates. Even though the author considered income level, which represents the indirect technique effect of trade on energy intensity, some important determinants of energy saving considered vital in the energy literature are still missing, namely foreign aid and industry value added. Besides, in their analysis, Adom and Adams (2018) regarded industry value-added as one of the drivers of energy consumption in Nigeria. Accordingly, it is appropriate to investigate further the determinants of energy conservation in the country.

\section{Models, data and methodology}

\section{A. Model specification}

The preliminary argument of the theoretical background in the present study is that trade liberalization might be a determinant of energy intensity. For example, increased exports and imports may likely increase competition among domestic firms, which in turn may lead to more technological (see Hübler \& Keller, 2010). It is well-established in the energy economics literature that industry value added is also an important factor influencing the composition effect of economic activities on energy intensity, including the sectoral shift (see, for instance, Murtishaw \& Schipper, 2001; Fredriksson, Vollebergh \& Dijkgraaf, 2004; Zha, Zhou, \& Ding, 2009; Hübler \& Keller, 2010; Che \& Pham, 2012) . This is in addition to the relationship between energy use and real income under the Antweiler, Copeland \& Taylor (commonly known as the ACT) framework adapted by Cole (2006). At a higher income level, there may be a higher public demand for a cleaner environment that might result in the enforcement of stricter environmental regulations. This may stimulate a reaction from domestic firms through the introduction of 'clean/green' technologies that can reduce energy use (Antweiler et al. 2001; Jibrilla \& Ismail, 2015). Following Cole (2006), the present study considers using initial real GDP per capita to capture the technique effects of income level.

Another essential determinant of energy use as suggested in the literature is official development assistance and aid inflows, commonly known as foreign aid (Hübler \& Keller, 2010; Martinot, Chaurey, Lew, Moreira \& Wamukonya, 2002). Aid advocates are of the view that, foreign aid (typically) from advanced countries to developing ones help the latter to accelerate their economic growth through providing them with new knowledge and technology transfer (Mosley, Hudson \& Horrell, 1987). Therefore, the relationship between energy intensity and its determinants can be specified as follows 


$$
E I_{t}=f\left(T R O_{t}, Y_{t}, A I D_{t} I V A D_{t}\right)
$$

where EIdenotes British thermal units $(\mathrm{Btu})$ of energy intensity (proxies by primary energy use per unit of real GDP measured in U.S. Dollars), TRO is the trade intensity (exports plus imports as a share of GDP), $Y$ is real income (per capita real GDP in US Dollars), AID is the official development assistance and aid inflows, and IVAD represents proxies of industry value added (including Agriculture value added per worker at a constant 2010 US Dollars and manufacturing value added as a share of GDP).

Expressing eqn. (1) in logarithms and differentiating it with respect to time yields the empirical model to be estimated as follows

$$
\operatorname{InEI}_{t}=\alpha_{0}+\alpha_{1} \ln T R O_{t}+\alpha_{2} \ln Y_{t}+\alpha_{3} \ln A I D_{t}+\alpha_{4} \ln I V A D_{t}+\varepsilon_{t}
$$

where at year $\mathrm{t}, \ln E I$ is the natural $\log$ of energy intensity, $\ln T R O$ is the natural $\log$ of trade intensity, $\ln Y$ is the natural $\log$ of real income level, $\ln A I D$ is the natural $\log$ of foreign aid (Net official development assistance and aid inflows), $\operatorname{lnIVAD}$ is the natural log of the industry value added, $\alpha_{0}$ denotes the intercept term, $\alpha_{1}, \alpha_{2}, \alpha_{3}$ and $\alpha_{4}$ are the coefficients of the explanatory variables, which represent the long-run elasticity estimates of energy intensity with respect to regressors identified in equation (2)and $\varepsilon$ is the disturbance term assumed to be purely random.

From equation (2), for the Nigerian trade to have energy saving effect in Nigeria, the coefficient $\alpha_{1}$ is expected to be negative and statistically significant, TRO. It is also expected that development assistance and aid, AID from advanced countries might stimulate energysaving technologies in Nigeria. However, Bell (1966) notes that this effect might depend on the country's assimilating capacity, giving rise to the possibility of counterintuitive. In addition, the country's income level might reduce the intensity of energy use. Regarding the industry value added, IVAD, persistence was observed in its growth rates for which (annual) data were available (see figure A1 in appendix A). As such, the expected of coefficient is indeterminate.

\section{B. Data}

This study used annual time series covering the period 1981-2015: energy intensity (proxies by primary energy use per unit of real GDP measured in U.S. Dollars), trade intensity (measured as the ratio of imports plus exports to GDP), per capita real GDP (measured in U.S. Dollars), foreign aid (Net official development assistance and aid inflows), and industry value added (as a share of GDP). Data on energy intensity are obtained from the 
US Energy Information Administration (2018). Data on all other variables have been collected from the online database of the World Bank's world development indicators (WDI, 2018). The definition and unit of measurement, descriptive statistics, and plots of log values of the variables used are presented in table 1 , table 2 and figure 1 , respectively.

Table 1: Definition of study variables

\begin{tabular}{|c|c|c|c|}
\hline Variables & Definition & Unit measurement & Source \\
\hline EI & $\begin{array}{l}\begin{array}{l}\text { Energy Intensity in } \\
\text { exchange rates }\end{array} \begin{array}{r}\text { (total } \\
\text { energy }\end{array} \\
\text { Primary } \\
\text { consumption per Dollar of } \\
\text { GDP) }\end{array}$ & $\begin{array}{l}\text { Btu per (constant } 2010 \\
\text { U.S. Dollars) }\end{array}$ & $\begin{array}{l}\text { US Energy } \\
\text { Information } \\
\text { Administrati } \\
\text { on (Online, } \\
\text { 2018) }\end{array}$ \\
\hline $\mathrm{Y}$ & $\begin{array}{l}\text { Per capita income (measured } \\
\text { by real GDP) }\end{array}$ & $\begin{array}{ccc}\begin{array}{c}\text { Constant } \\
\text { dollars }\end{array} & 2010 \quad \text { US } \\
\end{array}$ & $\begin{array}{l}\text { World Bank } \\
\text { (Online, } \\
\text { 2018) }\end{array}$ \\
\hline TRO & $\begin{array}{l}\text { Trade intensity (exports plus } \\
\text { imports as a share of GDP) }\end{array}$ & - & $\begin{array}{l}\text { World Bank } \\
\text { (Online, } \\
\text { 2018) }\end{array}$ \\
\hline AID & $\begin{array}{l}\text { Official development } \\
\text { assistance and aid inflows } \\
\text { as a Share of GDP }\end{array}$ & - & $\begin{array}{l}\text { World Bank } \\
\text { (Online, } \\
\text { 2018) }\end{array}$ \\
\hline IVAD & $\begin{array}{l}\text { Share of industry value in } \\
\text { GDP }\end{array}$ & - & $\begin{array}{l}\text { World Bank } \\
\text { (Online, } \\
\text { 2018) }\end{array}$ \\
\hline
\end{tabular}

Table 2: Descriptive statistics of the variables for the period 1981-2015

\begin{tabular}{|l|l|l|l|l|c|}
\hline & Mean & Median & Min. & Max. & Standard deviation \\
\hline EI & 1.535273 & 1.821479 & 0.000000 & 2.597197 & 0.906038 \\
\hline Y & 1647.176 & 1410.679 & 1151.126 & 2563.092 & 465.4531 \\
\hline TRO & 51.12237 & 53.03022 & 21.33265 & 81.81285 & 16.59182 \\
\hline IVAD & 51.14571 & 44.02049 & 20.16078 & 104.6372 & 22.01503 \\
\hline AID & $1.18 \mathrm{E}+09$ & $3.36 \mathrm{E}+08$ & 91170000 & $1.13 \mathrm{E}+10$ & $2.16 \mathrm{E}+09$ \\
\hline
\end{tabular}

Figure 1 illustrates the logarithmic form of energy intensity, real per capita GDP, trade intensity, industry value added and foreign aid. It seems that all these series on average demonstrate common trends. The fact that most of these data follow a common trend tended to suggest that they have the potential of strong causal effects. This also indicates that a large portion of the change in energy intensity in Nigeria can be attributed to changes in real per capita GDP, trade intensity, industry value added and foreign aid. 
Figure 1: Logarithmic of energy intensity, economic growth, trade intensity, industry value added and foreign aid

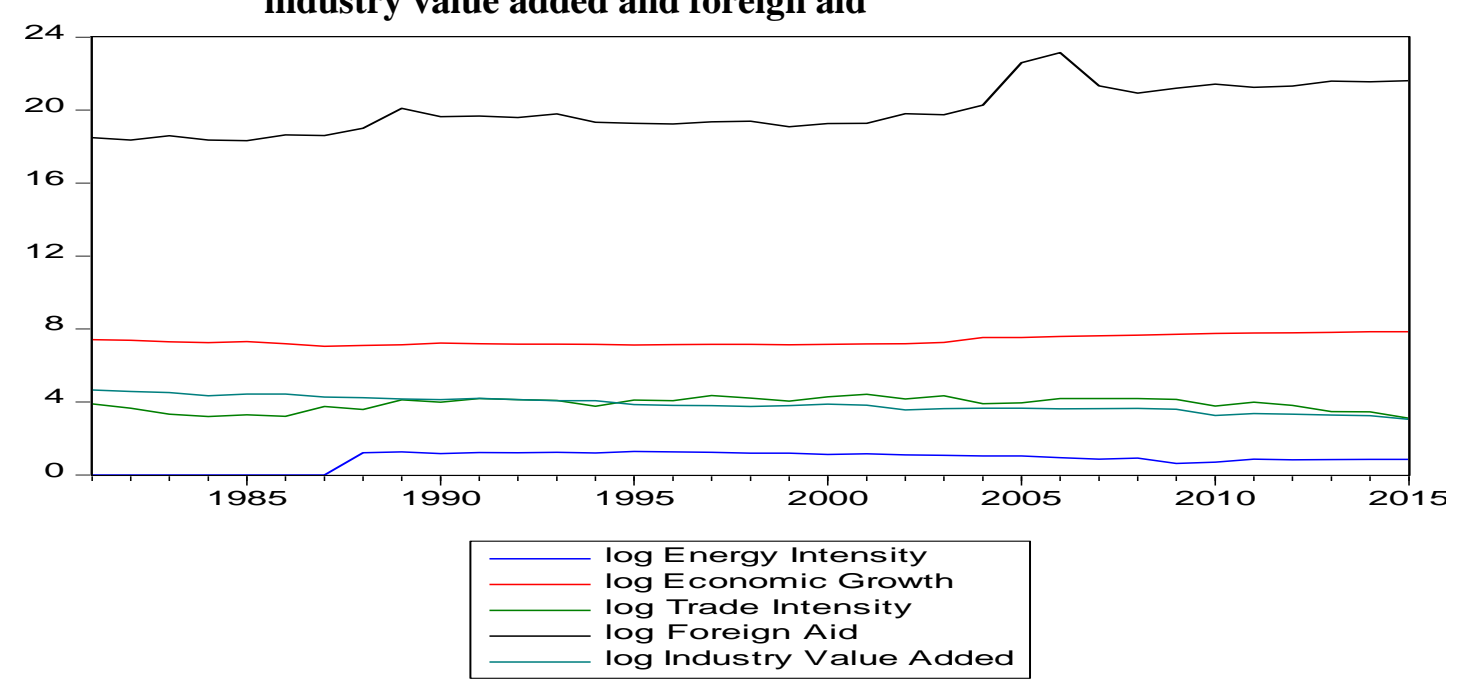

\section{Methodology}

To estimate equation (2), the autoregressive distributed lag (ARDL) Cointegration technique, also known as bounds testing to Cointegration introduced by Pesaran and Shin (1999) and later extended by Pesaran et al. (2001) were employed. This approach has a number of advantages in comparison to other well-known Cointegration procedures such as Engle and Granger (1987), Johansen and Juselius (1990) and Johansen (1996) among others. First, unlike these procedures, the ARDL methodology does not require that all the variables under consideration must be integrated of the same order. That is, it avoids pretesting the order of integration of the individual variables. Thus, it allows estimation of equation (2) regardless of whether the variables therein are purely I (0), purely I (1) or are mutually co integrated (Pesaran et al., 2001). Second, whereas some other Cointegration techniques require a large sample size, the ARDL approach can produce consistent and efficient estimates even when the sample size is small (see Pesaran \& Shin, 1999; Narayan \& Narayan, 2005). Third, the ARDL can provide unbiased and robust long-run estimates even when the estimated regression contains some endogenous regressors (see also Halicioglu, 2009; Odhiambo, 2009; Bildirici \& Kayıkç1, 2013; Samargandi, Fidrmuc \& Ghosh, 2015).

Although by construction, the ARDL approach is robust to the presence of a unit root, as a first step, the analysis will start by examining the integration properties of the variables by applying the Augmented Dickey-Fuller (ADF), the Philips Perron (PP) and Kwiatkowski- 
Phillips-Schmidt-Shin (KPSS) unit root tests. The ADF, PP and KPSS unit root tests for the null hypothesis of a unit root in the series is tested against the alternative hypothesis of stationarity. The KPSS is, however, shown to have a high power test compared to ADF and PP (see Hobijn, Franses \& Ooms, 2004; Wang \& Tomek, 2007). The results of the unit root tests are presented in tables $3 \& 4$.

\section{Results and discussion}

\section{A. Unit root tests}

The test results reported in Table 3 reveal that, except for industry value added and the foreign aid (which are shown to be stationary at better than the 10 significance level, all the remaining variables are found to be non-stationary at their levels. Results from the first differences of all the series suggest that for ADF, only the trade intensity variable is found to be nonstationary at the first difference of the series. Conversely, both the PP and KPSS unit root test results reject the null hypothesis of a unit root for all the series considered in the analysis, suggesting that all the variables are integrated of order one, I(1).

Table 3: $\quad$ Results of the ADF, PP and KPSS unit root tests

\begin{tabular}{|c|c|c|c|}
\hline \multirow[t]{2}{*}{ Variables } & \multicolumn{3}{|l|}{ Levels } \\
\hline & ADF & $\mathbf{P P}$ & KPSS \\
\hline $\ln \mathbf{E I} I_{t}$ & $-1.707191(0.7261)$ & $-1.705879(0.7267)$ & $0.177562 * *[0.1460]$ \\
\hline $\ln Y_{t}$ & $-2.099368(0.5277)$ & $-2.098002(0.5284)$ & $0.198338 * *[0.1460]$ \\
\hline $\ln \mathrm{TRO}_{\mathrm{t}}$ & $1.610495(1.0000)$ & $-1.132881(0.9082)$ & $0.181191 * *[0.1460]$ \\
\hline $\operatorname{lnIVAD} D_{t}$ & $-3.757499 * *(0.0317)$ & $-3.782607 * *(0.0300)$ & $0.122198 *[0.1190]$ \\
\hline $\ln \mathrm{AID}_{\mathrm{t}}$ & $-3.389601 *(0.0701)$ & $-2.668383(0.2550)$ & $0.075738[0.1460]$ \\
\hline \multicolumn{4}{|c|}{ First differences } \\
\hline$\Delta \operatorname{lnEI}_{\mathbf{t}}$ & $-5.637531 * * *(0.0000)$ & $-5.637531 * * *(0.0000)$ & $.219484[0.4630]$ \\
\hline$\Delta \ln Y_{t}$ & $-4.345355 * * *(0.0016)$ & $-4.331195 * * *(0.0017)$ & $\underline{0.198338[0.4630]}$ \\
\hline$\Delta \ln \mathrm{TRO}_{\mathrm{t}}$ & $-2.150309(0.2279)$ & $-7.321750 * * *(0.0000)$ & $0.185280[0.4630]$ \\
\hline$\Delta \operatorname{lnIVAD} \mathbf{D}_{\mathrm{t}}$ & $-6.753601 * * *(0.0000)$ & $-9.223447 * * *(0.0000)$ & $0.179453[0.4630]$ \\
\hline$\Delta \ln \mathrm{AID}_{\mathrm{t}}$ & $-5.691489 * * *(0.0000)$ & $-7.449630 * * *(0.0000)$ & $0.257902[0.4630]$ \\
\hline
\end{tabular}

Note: $* * *, * *$ and $*$ denote the rejection of the null hypothesis at the $1 \%, 5 \%$ and $10 \%$ significant level, respectively. Lag length for $\mathrm{ADF}$ was chosen by Akaike information criterion (AIC). Bandwidth for PP and KPSS using Bartlett Kernel. Figures in square brackets are critical values (as software used do not report p-values of KPSS test results).

Since the unit root test results clearly show the mixture of stationary, I(0), and integrated, I(1) series; they should, therefore, appear in the univariate Cointegration test using ARDL technique. Further, given the weak powers of both the ADF and the PP tests compared to KPSS tests when the true root is near unity, the present analysis considers KPSS test results. 


\section{B. Cointegration tests}

The ARDL bounds testing approach to Cointegration suggest testing the existence of the possible long run relationship between energy intensity and its determinants in Nigeria based on the following error correction regressions (Pesaran \& Pesaran, 1997; Pesaran et al., 2001; Narayan \& Narayan, 2005)

$$
\begin{aligned}
\Delta \ln E I_{t} & =\delta_{0 E I}+\psi_{1 E I} \ln E I_{t-1}+\psi_{2 E I} \ln T R O_{t-1}+\psi_{3 E I} \ln Y_{t-1}+\psi_{4 E I} \ln A I D_{t-1}+\psi_{5 E I} \ln I V A D_{t-1} \\
& +\sum_{i=1}^{p} \alpha_{i E I} \Delta \ln E I_{t-i}+\sum_{i=0}^{p} \beta_{i E I} \Delta \ln T R O_{t-i}+\sum_{i=0}^{p} \varpi_{i E I} \Delta \ln Y_{t-i}+\sum_{i=0}^{p} \lambda_{i E I} \Delta A I D_{t-i}+\sum_{i=0}^{p} \gamma_{i E I} \Delta \ln I V A D_{t-i}+v_{1 t}
\end{aligned}
$$

Where $\Delta$ symbolizes the first difference operator, all the remaining variables are as defined in Eqn. (2). The lag orders in equation (3) are chosen based on Akaike Information Criteria (AIC) and the selected model was estimated using the standard ordinary least squares technique (OLS). The presence of long-run relationship among the variables was examined by Bounds test using F-test statistic. The null hypothesis for this test, which indicates no Cointegration is Ho: $\psi_{1 \mathrm{EI}}=\psi_{2 \mathrm{EI}}=\psi_{3 \mathrm{EI}}=\psi_{4 \mathrm{EI}}=\psi_{5 \mathrm{EI}}=0$ denoted by $F_{E I}(E I / T R O, Y, A I D$, $I V A D)$ against the alternative hypothesis $\mathrm{H} 1: \psi_{1 \mathrm{EI}} \neq \psi_{2 \mathrm{EI}} \neq \psi_{3 \mathrm{EI}} \neq \psi_{4 \mathrm{EI}} \neq \psi_{5 \mathrm{EI}} \neq 0$.

The asymptotic distribution of the $F$ test that can be used to examine the null hypothesis has a nonstandard distribution with two sets of critical values for certain significance levels in Pesaran et al. (2001). While the first set assumes that all the series are $\mathrm{I}(0)$, in the second set, all series are assumed to be I(1). These critical values, however, depend on (i) the sample size (ii) the number of regressors (iii) whether the series are I(0) or I(1), and (iv) whether the ARDL model contains an intercept and/or a trend (see, e.g. Pesaran, Shin \& Smith, 2001). If the estimated F-statistics falls outside the upper bounds of I(1), a conclusion can be made that Cointegration exist among the variables, whereas the conclusion for the nonexistence of Cointegration can be made if the computed F-statistics falls below the lower bound of $\mathrm{I}(0)$. However, if the calculated F-statistics falls in between the two bounds, then no conclusion can be made regarding the existence of the long - run relationship between the variables.

\section{Long run elasticities}

Table 4: ADRL bound test results for Cointegration relationship

\begin{tabular}{|l|l|l|l|}
\hline $\begin{array}{l}\text { FEI(EI/Y, TRO, IVAD, } \\
\text { AID) }\end{array}$ & $\begin{array}{l}\text { Critical value of the F statistic for the bounds test } \\
\text { results with intercept and no time trend }\end{array}$ \\
\cline { 2 - 4 } \\
Computed F-statistics & Sig. level & Lower bounds & Upper bounds \\
\hline
\end{tabular}


Pakistan Journal of Humanities and Social Sciences, 6(4), 2018

\begin{tabular}{|l|l|l|l|}
\hline $\mathbf{3 . 5 1} * *$ & $99 \%$ level & 3.29 & 4.37 \\
\hline $\mathbf{K}=\mathbf{4}$ & $95 \%$ level & 2.56 & 3.49 \\
\hline & $90 \%$ level & 2.20 & 3.09 \\
\hline
\end{tabular}

Notes: ** indicate rejection of the null hypothesis of no Cointegration at $5 \%$ significance level.

The calculated F-statistic $\mathrm{F}_{\mathrm{EI}}(\mathrm{EI} / \mathrm{Y}, \mathrm{TRO}, \mathrm{IVAD}, \mathrm{AID})=3.51$ for equation (3) appears to be slightly greater than the critical value (3.49) of the upper bound at the $5 \%$ significance level (Table 4). The test results lead to the conclusion that there is convincing evidence of co integration between energy intensity and its determinants for Nigeria. Since co integration exist between the variables, the next step is to estimate the long-run coefficients of equation (2) using the ARDL technique as follows

$\ln E I_{t}=\alpha_{0}+\sum_{i=1}^{p} \alpha_{1 i} \ln E I_{t-i}+\sum_{i=0}^{p} \alpha_{2 i} \ln T R O_{t-i}+\sum_{i=0}^{p} \alpha_{3 i} \ln Y_{t-i}+\sum_{i=0}^{p} \alpha_{4 i} A I D_{t-i}+\sum_{i=0}^{p} \alpha_{5 i} \ln I V A D_{t-i}+\varepsilon_{1 t}$

(4)

Although, the ARDL can handle the issue of endogeneity, since it includes lags of both dependent and explanatory variables (Pesaran et al., 1999), the ARDL results will be assessed further using dynamic OLS (DOLS) methodology, proposed by Stock and Watson (1993). The DOLS approach produces asymptotically efficient and consistent estimations in the existence of endogeneity and autocorrelation problems (see Stock \& Watson, 1993; Esteve \& Requena, 2006). The DOLS estimator of (4) can be expressed as

$$
y_{t}=\alpha_{0}+z_{t}^{\prime} \beta+\sum_{j=-l}^{l} \Omega_{j} \Delta z_{t-j}+v_{t}
$$

Where $\beta$ is a $(\mathrm{K} \times 1)$ vector of the slopes of the regressors, $z_{t}^{\prime}$ is a $(\mathrm{K} \times 1)$ vector of the autoregressive process of the first order difference of the explanatory variables: $z_{t}=z_{t-1}+\varepsilon_{t}$ and, $\varepsilon_{t}$ is the usual error term. Moreover, the present analysis has a clear concern about the stability of the long-run energy intensity, which has important implications for the accuracy of both the ARDL and DOLS estimates. To determine parameter stability in the energy intensity equation, Hansen (1992) stability test was applied. Beside the estimation of the long run ARDL equation, the short run dynamics within an error correction model is estimated as follows:

$$
\begin{aligned}
\Delta \ln E I & =\delta_{0}+\sum_{i=1}^{p} \alpha_{i E I} \Delta \ln E I_{t-i}+\sum_{i=0}^{p} \beta_{i E I} \Delta \ln T R O_{t-i}+\sum_{i=0}^{p} \varpi_{i E I} \Delta \ln Y_{t-i}+\sum_{i=0}^{p} \lambda_{i E I} \Delta A I D_{t-i} \\
& +\sum_{i=0}^{p} \gamma_{i E I} \Delta \ln I V A D_{t-i}+\eta_{1} E C T_{t-1}+\varepsilon_{1 t}
\end{aligned}
$$


Table 5: Estimated long-run and short run coefficients (Dependent variable: Energy intensity)

\begin{tabular}{|c|c|c|}
\hline Variables & $\operatorname{ARDL}(1,3,0,2,1)$ & DOLS \\
\hline $\begin{array}{l}\text { Panel A: Long run } \\
\text { results } \\
\text { Intercept }\end{array}$ & $\begin{array}{l}20.068 * * * \\
(6.499) \\
(3.088)\end{array}$ & $\begin{array}{l}20.268 * * \\
(8.073)\end{array}$ \\
\hline $\operatorname{lnTRO}_{\mathrm{t}}$ & $\begin{array}{l}-.3896 \\
(.3513) \\
(-1.1090) \\
\end{array}$ & $\begin{array}{l}-.2391 \\
(.5113)\end{array}$ \\
\hline $\ln Y_{t}$ & $\begin{array}{l}-3.923 * * * \\
(1.022) \\
(-3.8386)\end{array}$ & $\begin{array}{l}-3.424 * * * \\
(1.109)\end{array}$ \\
\hline $\ln \mathrm{AID}_{\mathrm{t}}$ & $\begin{array}{l}.7310 * * * \\
(.2260) \\
(3.2345)\end{array}$ & $\begin{array}{l}.4978^{* *} \\
(.2106)\end{array}$ \\
\hline $\operatorname{lnIVAD}_{\mathrm{t}}$ & $\begin{array}{l}-0.856^{* *} \\
(.3325) \\
(-2.5744) \\
\end{array}$ & $\begin{array}{l}-.8400 * * \\
(.3822)\end{array}$ \\
\hline \multicolumn{3}{|c|}{ Panel B: Short run results } \\
\hline$\Delta \ln \mathrm{TRO}_{\mathrm{t}}$ & $\begin{array}{l}-0.2979 * * \\
(.1272) \\
(-2.3420)\end{array}$ & \\
\hline$\Delta \ln Y_{t}$ & $\begin{array}{l}-0.7715 \\
(.4929) \\
(-1.5652) \\
\end{array}$ & \\
\hline$\Delta \ln Y_{t(-1)}$ & $\begin{array}{l}-1.1541^{* *} \\
(.4775) \\
(-2.4180)\end{array}$ & \\
\hline$\Delta \ln Y_{t(-2)}$ & $\begin{array}{l}-1.2841^{* *} \\
(.4547) \\
(-2.8241)\end{array}$ & \\
\hline$\Delta \ln \mathrm{AID}_{\mathrm{t}}$ & $\begin{array}{l}.2912 * * * \\
(.0586) \\
(3.4019)\end{array}$ & \\
\hline$\Delta \ln \mathrm{AID}_{\mathrm{t}(-1)}$ & $\begin{array}{l}-0.1640 * * \\
(.0581) \\
(-2.8227)\end{array}$ & \\
\hline$\Delta \operatorname{lnIVAD} \mathrm{t}_{\mathrm{t}}$ & $\begin{array}{l}.1241 \\
(.2531) \\
(0.4903)\end{array}$ & \\
\hline ecm(-1) & $\begin{array}{l}-.5030 * * * \\
(.0930) \\
(-5.4080)\end{array}$ & \\
\hline \multicolumn{3}{|c|}{ Panel C: Diagnostic checks } \\
\hline$\chi_{\text {Norm }}^{2}(3)$ & $\begin{array}{l}3.402 \\
{[.1825]}\end{array}$ & \\
\hline$\chi_{L M}^{2}(3)$ & 1.913 & 1.700 \\
\hline
\end{tabular}




\begin{tabular}{|l|l|l|}
\hline & {$[.5908]$} & $(.4279)$ \\
\hline$\chi_{B G}^{2}(3)$ & 13.782 & \\
\hline$\chi_{A R C H}^{2}(3)$ & {$[.2453]$} & \\
\hline $\begin{array}{l}\text { Panel D: Hansen } \\
\text { instability test }\end{array}$ & 3.733 & \\
\hline \multicolumn{1}{|c|}{$\mathbf{L}_{\mathbf{C}}$} & & \\
& & .0369 \\
\hline
\end{tabular}

Notes: $* *$ and $* * *$ indicates rejection of hypothesis at the $5 \%$ and $1 \%$ significance levels, respectively. Figures in parentheses standard errors and numbers in curly brackets are probability values. $\chi_{\text {Norm }}^{2}$ is the Jarque-Bera test for normality, $\chi_{\text {LMis }}^{2}$ the Serial Correlation LM Test, and $\chi_{\text {wT }}^{2}$ is the white hetroskedasticity test. The lags used to estimate the ARDL model as well as the lags and leads used to estimate the DOLS model are chosen based on Schwarz information criterion (SIC). $\Delta$ lnYt represents change in economic growth, $\Delta \ln$ TROt denotes change in trade intensity, $\Delta \ln$ AIDt is change in foreign aid and, $\Delta \operatorname{lnIVADt}$ signifies change

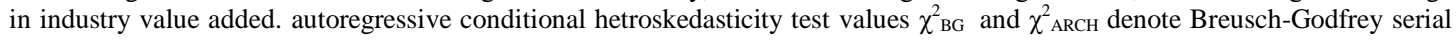
correlation (LM) test and the autoregressive conditional hetroskedasticity (ARCH) test. Italicized figure in brackets are tstatistics

Where $\Delta$ is the first difference operator, $k$ is the optimal lag length of the differenced variables determined by the Schwarz information criterion at the $5 \%$ level. $\varepsilon_{t}$ 's are the error terms assumed to be purely random. The $E C T_{t-1}$ term in Equation (6) represents the co integrating vector and $\eta_{i}$ is the error correction coefficient that shows by how much any deviation is adjusted back to the long-run equilibrium. As a rule for any deviation to adjust back to the long-run equilibrium, $\eta_{i}$ has to be negative and statistically significant. The estimated long-run and short-run coefficients are presented in Table 5.

Table 5 presents estimated results for ARDL and DOLS models. It can be noted from these results that the slope coefficient of the DOLS model appears roughly similar to that of ARDL. The estimated coefficient on the measure of trade intensity in both the models (ARDL \& DOLS of model 1) appears negative, but not statistically significant at the conventional levels as far as can be detected in the data used, although it appears to significantly reduce the intensity of energy use in the short run. The per capita income variable which captures the technique effect enters with a negative sign, as expected, which confirms the finding by Cole (2006) and, Hübler and Keller (2010). Besides, this effect is also observed in the short run, although the effects only start having a significant effect from the first lag period. This finding appears to indicate that the technology effect of higher economic growth is larger in magnitude than the trade intensity effect. Results in Table 5 also shows that, while foreign aid seems to be positively associated with energy intensity in Nigeria, and industry value added appears to reduce the intensity of energy at the conventional significance level. It is worthy of note that, the observed associations appear similar across both techniques applied; although, their short run estimates appear opposite to that of long-run estimates. This tended 
to suggest that the results are reasonably robust. The estimated coefficients show that every $1 \%$ increase in foreign aid is associated with as much as .73\% increase in the energy intensity. Moreover, the estimated long-run elasticities from the two estimators show that a $1 \%$ rise in the industry value added lead to approximately $.84 \%$ to $.86 \%$ decrease in energy intensity.

The estimated negative association between energy intensity and the industry value added, which appears contrary to that of Hübler and Keller (2010) tends to demonstrate that primary industry and perhaps emergent service industries are the likely dominant form of industrial activity in Nigeria. It should be noted that due to data unavailability, the present analysis is unable to identify the trade-induced composition effect within the aggregated industry sector that includes manufacturing mining, construction, electricity, water, and gas. The energy-intensity increase by foreign aid inflows is inconsistent with the expectations that foreign aid might promote energy-saving technologies. Although it is outside the scope of this study to fully explore the possible causes for the inability of aid to reduce energy intensity, it is possible to suggest a number of factors that may have led to the observed result (positive coefficient). The observed increasing effect of foreign aid on energy intensity in Nigeria may have been caused by weak institutions (see, for example, Bräutigam \& Knack, 2004). Although it has been argued, aid could provide a channel for technology or knowledge transfer from advanced nations to lower-income countries (Radelet, 2006; Hübler \& Keller, 2010).

As regards to the error correction term, for the energy intensity model, the results show that the ECT(-1) term is negative and statistically significant, indicating the effectiveness of feedback mechanism in Nigeria in stabilizing the energy use. The intensity of energy use adjust at the speed of about $50 \%$ or it will take Nigeria roughly 1 year, 6 months to reach the long-run equilibrium when there is any shock in the energy use. It is important to note, however, that these results need to be interpreted with caution given the relatively shortsample size used in this study.

In the diagnostic checks, the residual diagnostics of normality, serial correlation and heteroskedasticity tests in panel $\mathrm{C}$ of Table 5 failed to indicate that the estimated regression deviates from the standard assumptions. Again, the stability tests of recursive residuals using CUSUM and CUSUM Squares (Appendix B) indicate that the estimated ARDL model is free from misspecification, and all the coefficient estimates are relatively stable respectively at the 5\% significance level. In addition, Hansen instability test (Panel D) provides evidence for parameter stability at conventional levels of significance. 


\section{Conclusion and policy implications}

Based on the theory proposed by Antweiler, Copeland, and Taylor (ACT, 2001), this study examines whether trade openness reduces the intensity of energy use of the production process in Nigeria. Such cutbacks are necessary to reduce emissions of greenhouse gases since energy use is strongly related to pollution emissions. The results show that, although trade openness tends to reduce energy intensity in the short run, it appears that the intensity of trade in the country may not be sufficient enough to have that impact in the long run. Moreover, the results suggest that energy use per real economic growth is subject to technique effect, demonstrating that improvement in energy management is corresponding with real growth in the national income.

With regard to the foreign aid, evidence found that it might have been limited by lack of proper support from the domestic capacity to impact positively on energy efficiency in Nigeria. Finally, evidence regarding the composition effect tends to suggest that production process in the country may still be dominated by primary production with some likely positive effects from the service sector (although that is not empirically tested in the present study).

The policy implications of these findings are that: (i) with the negative (but not significant) association between energy intensity and trade liberalization. Nigeria has a future potential to achieve sustainable energy with more openness to international trade, thus suggesting the need for more effective policies that enhances trade openness in the country (ii) the evidence of negative impact of growth on energy intensity appears to indicate that higher growth will influence higher demand for energy efficiency in the production process and (iii) the positive impact of foreign aid on energy intensity tended to suggest that energy efficiency gains through foreign aid in Nigeria is not automatic but rather may occur with proper support from domestic policies.

Finally, the evidence provided by this study seems to indicate that if the country becomes more committed to providing an enabling environment suitable for attracting inward technology transfer can complement domestic policies directed to enhance energy efficiency in Nigeria. More of this effort will ensure proper utilization of foreign aids and improve energy management, particularly in the industrial sector is desirable to make the energy conservation more sustainable. 


\section{References}

ADB. (2018). Nigeria Economic Outlook. Retrieved February 6, 2018, from https://www.afdb.org/en/

Adom, P. K. (2015). Asymmetric impacts of the determinants of energy intensity in Nigeria. Energy Economics, 49, 570-580.

Aderemi, A. O., Ilori, M. O., Aderemi, H., \& Akinbami, J. F. K. (2009). Assessment of electrical energy use efficiency in Nigeria food industry.African Journal of Food Science, 3(8), 206-216.

Advisory Group on Energy and Climate Change (2010). Energy for a Sustainable Future. Tech. rep. New York: United Nations.

Aiyedun, O. P., \& Adeyemi, A. O. (2008). Energy Efficiency of a Manufacturing Industry: A Case Study Of Nigeria Eagle Flour Mills Limited, Ibadan. ASSET: An International Journal (Series B)\}, 7(2), 91-103.

Allison, P. D. (2009). Fixed effects regression models (Vol. 160). London, SAGE publications.

Ang, J. B. (2009). CO 2 emissions, research and technology transfer in China. Ecological Economics, 68(10), 2658-2665.

Antweiler, W., Copeland, B. R., \& Taylor, M. S. (2001). Is Free Trade Good for the Environment?. American Economic Review, 91(4), 877-908.

Anyanwu, J. C. (1992). President Babangida's structural adjustment programme and inflation in Nigeria. Journal of Social Development in Africa,7(1), 5-24.

Apergis, N., Filippidis, I., \& Economidou, C. (2007). Financial deepening and economic growth linkages: a panel data analysis. Review of World Economics,143(1), 179-198.

Balli, H. O., \& Sørensen, B. E. (2013). Interaction effects in econometrics. Empirical Economics, 45(1), 583-603.

Baltagi, B. H., Demetriades, P. O., \& Law, S. H. (2009). Financial development and openness: Evidence from panel data. Journal of development economics, 89(2), 285296.

Bell, D. E. (1966). The quality of aid. Foreign Affairs, 44(4), 601-607.

Bildirici, M. E., \& Kayıkçı, F. (2013). Effects of oil production on economic growth in Eurasian countries: Panel ARDL approach. Energy, 49, 156-161.

Brambor, T., Clark, W. R., \& Golder, M. (2006). Understanding interaction models: Improving empirical analyses. Political analysis, 14(1), 63-82.

Bräutigam, D. A., \& Knack, S. (2004). Foreign Aid, Institutions, and Governance in Sub-Saharan Africa*. Economic development and cultural change, 52(2), 255-285.

Burril, D. (2006). Modeling and interpreting interactions in multiple regression. Available at: https://www.minitab.com/uploadedFiles/.../interactions_in_multiple_regression.pdf (accessed 2 February 2016).

Büthe, T., \& Milner, H. V. (2008). The politics of foreign direct investment into developing countries: increasing FDI through international trade agreements?. American Journal of Political Science, 52(4), 741-762.

Cecelski, E. (2003) Enabling equitable access to rural electrification: current thinking on energy, poverty and gender. Washington, D.C.: World Bank; 2003.

Chokor, B. A. (1993). Government policy and environmental protection in the developing world: The example of Nigeria. Environmental Management,17(1), 15-30.

Chontanawat, J., Hunt, L. C., \& Pierse, R. (2008). Does energy consumption cause economic growth?: Evidence from a systematic study of over 100 countries. Journal of Policy Modeling, 30(2), 209-220. 
Pakistan Journal of Humanities and Social Sciences, 6(4), 2018

Che, N., \& Pham, P. (2012). Economic analysis of end-use energy intensity in Australia. Australian Government. Canberra: Bureau of Resources and Energy Economics.

Chete, L. N., Adeoti, J. O., Adeyinka, F. M., \& Ogundele, O. (2014).Industrial development and growth in Nigeria: Lessons and challenges (No. 2014/019). WIDER Working Paper. Available at: http://citeseerx.ist.psu.edu/viewdoc/download?doi=10.1.1.1014.9507\&rep=rep1\&typ $\underline{\mathrm{e}=\mathrm{pdf}}$ (accessed 2 September 2017).

Cole, M. A. (2006). Does trade liberalization increase national energy use?. Economics Letters, 92(1), 108-112.

Cole, M. A., \& Elliott, R. J. (2003). Determining the trade-environment composition effect: the role of capital, labor and environmental regulations. Journal of Environmental Economics and Management, 46(3), 363-383.

Dickey, D. A., \& Fuller, W. A. (1979). Distribution of the estimators for autoregressive time series with a unit root. Journal of the American statistical association, 74(366a), 427431.

DiLalla, L. F., \& Mullineaux, P. Y. (2008). The effect of classroom environment on problem behaviors: A twin study. Journal of School Psychology, 46(2), 107-128.

Eaton, J., \& Kortum, S. (1996). Trade in ideas Patenting and productivity in the OECD. Journal of international Economics, 40(3), 251-278.

Engle, R. F., \& Granger, C. W. (1987). Co-integration and error correction: representation, estimation, and testing. Econometrica: journal of the Econometric Society, 251-276.

Esteve, V., \& Requena, F. (2006). A Cointegration analysis of car advertising and sales data in the presence of structural change. International Journal of the Economics of Business, 13(1), 111-128.

Federal Republic of Nigeria (FRN), Federal executive Council. (2015, May 20). National Renewable Energy and Energy Efficiency Policy (NREEEP): Federal Ministry of Power. Retrieved December 31, 2015, from http://www.power.gov.ng.

Federal Government of Nigeria (FGN), Federal Ministry of Environment. (1999). National policy on environment. Retrieved January 06, 2016, from http://environment.gov.ng.

Finger, C. A. (1994). The ability of earnings to predict future earnings and cash flow. Journal of accounting research, 32(2),210-223.

Frankel, J. A. (2009). Environmental Effects of International Trade. Harvard Kennedy School of Government. Harvard Kennedy School. Faculty Research Working Paper RWP 09-006, January 2009

Fredriksson, P. G., Vollebergh, H. R., \& Dijkgraaf, E. (2004). Corruption and energy efficiency in OECD countries: theory and evidence. Journal of Environmental Economics and management, 47(2), 207-231.

Fisher-Vanden, K., Jefferson, G. H., Liu, H., \& Tao, Q. (2004). What is driving China's decline in energy intensity?. Resource and Energy Economics, 26(1), 77-97.

Goshwe, N. Y., \& Kureve, T. D. (2012). Industrial Energy Management Opportunities in Nigeria: A Case Study of Energy Audit of VIK Industries Nigeria, Ltd. The Pacific Journal of Science and Technology, 13(1), 152-168.

Gregory, A. W., \& Hansen, B. E. (1996a). Residual-based tests for Cointegration in models with regime shifts. Journal of econometrics, 70(1), 99-126.

Grossman, G.M. and A.B. Krueger (1993), 'Environmental impacts of a North American free trade agreement', in Garber, P., ed., The Mexico-US Free TradeAgreement, Cambridge, MA: MIT Press.

Grossman, G. M., \& Krueger, A. B. (1995). Economic growth and the environment. The Quarterly Journal of Economics, 110(2), 353-377. 
Halicioglu, F. (2009). An econometric study of CO 2 emissions, energy consumption, income and foreign trade in Turkey. Energy Policy, 37(3), 1156-1164.

Hansen, B. E. (1992). Testing for parameter instability in linear models. Journal of policy Modeling, 14(4), 517-533.

Helpman, E., \& Rangel, A. (1999). Adjusting to a new technology: experience and training. Journal of Economic Growth, 4(4), 359-383.

Hobijn, B., Franses, P. H., \& Ooms, M. (2004). Generalizations of the KPSS-test for stationarity. Statistica Neerlandica, 58(4), 483-502.

Hsiao, C. (2003). Analysis of panel data. Cambridge university press, United Kingdom.

E, M., \& Keller, A. (2010). Energy savings via FDI? Empirical evidence from developing countries. Environment and Development Economics, 15(01), 59-80.

Ibrahim, M. H., \& Law, S. H. (2014). Social capital and CO2 emission-output relations: A panel analysis. Renewable and Sustainable Energy Reviews, 29, 528-534.

Jekayinfa, S. O., \& Bamgboye, A. I. (2008). Energy use analysis of selected palm-kernel oil mills in south western Nigeria. Energy, 33(1), 81-90.

Jibrilla A. A., \& Ismail, N. W. (2015). Foreign Direct Investment and Pollution Haven: Does Energy Consumption Matter in African Countries. Internal journal of Economics and Management, $9(S), 21-39$.

Johansen, S., \& Juselius, K. (1990). Maximum likelihood estimation and inference on Cointegration with applications to the demand for money. Oxford Bulletin of Economics and statistics, 52(2), 169-210.

Johansen, S. (1996). Likelihood-based inference in co integrated vector autoregressive models. Oxford University Press, Oxford.

Jung, C., Krutilla, K., \& Boyd, R. (1996). Incentives for advanced pollution abatement technology at the industry level: An evaluation of policy alternatives. Journal of environmental economics and management, 30(1), 95-111.

Kanagawa, M., \& Nakata, T. (2008). Assessment of access to electricity and the socioeconomic impacts in rural areas of developing countries. Energy policy, 36(6), 20162029.

Kaygusuz, K. (2011). Energy services and energy poverty for sustainable rural development. Renewable and sustainable energy reviews, 15(2), 936-947.

Keho, Y. (2016). Do Foreign Direct Investment and Trade lead to Lower Energy Intensity? Evidence from Selected African Countries. International Journal of Energy Economics and Policy, 6(1), 1-5.

Kneller, R. (2005). Frontier Technology, Absorptive Capacity and Distance*.Oxford Bulletin of Economics and Statistics, 67(1), 1-23.

Kose, M. A., Prasad, E. S., \& Terrones, M. E. (2006). How do trade and financial integration affect the relationship between growth and volatility? Journal of international economics, 69(1), 176-202.

Lermit, J., \& Jollands, N. (2001). Monitoring energy efficiency performance in New Zealand: a conceptual and methodological framework. National Energy Efficiency and Conservation Authority, Wellington.

Lescaroux, F. (2008). Decomposition of US manufacturing energy intensity and elasticities of components with respect to energy prices. Energy Economics, 30(3), 1068-1080.

Maji, I. K. (2015). Does clean energy contributes to economic growth? Evidence from Nigeria. Energy Reports, 1, 145-150.

Martinot, E., Chaurey, A., Lew, D., Moreira, J. R., \& Wamukonya, N. (2002). Renewable energy markets in developing countries*. Annual Review of Energy and the Environment, 27(1), 309-348. 
Pakistan Journal of Humanities and Social Sciences, 6(4), 2018

Mernier, A. (2012). The possible role of the energy charter in advancing energy for development in Africa. In Energy for Development (pp. 57-62). Springer Netherlands.

Mielnik, O., \& Goldemberg, J. (2002). Foreign direct investment and decoupling between energy and gross domestic product in developing countries. Energy policy, 30(2), 8789.

Mosley, P., Hudson, J., \& Horrell, S. (1987). Aid, the public sector and the market in less developed countries. The Economic Journal, 97(387), 616-641.

Murtishaw, S., \& Schipper, L. (2001). Disaggregated analysis of US energy consumption in the 1990s: evidence of the effects of the internet and rapid economic growth. Energy Policy, 29(15), 1335-1356.

Narayan, P. K. (2005). The saving and investment nexus for China: evidence from Cointegration tests. Applied economics, 37(17), 1979-1990.

Narayan, P. K., \& Narayan, S. (2005). Estimating income and price elasticities of imports for Fiji in a Cointegration framework. Economic Modelling, 22(3), 423-438.

Odedokun, M. O. (1996). Alternative econometric approaches for analysing the role of the financial sector in economic growth: Time-series evidence from LDCs. Journal of Development Economics, 50(1), 119-146.

Odhiambo, N. M. (2009). Energy consumption and economic growth nexus in Tanzania: an ARDL bounds testing approach. Energy Policy, 37(2), 617-622.

Olayinka, O. S., \& Oladele, A. T. (2013). Energy Audit of Manufacturing and Processing Industries in Nigeria: A Case Study of Food Processing Industry and Distillation \& Bottling Company. American Journal of energy research, 1(3), 36-44.

Oyedepo, S. O. (2012). Energy efficiency and conservation measures: tools for sustainable energy development in Nigeria. International Journal of Energy Engineering, 2(3), 86-98.

Perron, P. (1989). The great crash, the oil price shock, and the unit root hypothesis. Econometrica: Journal of the Econometric Society, 1361-1401.

Perron, P. (1997). Further evidence on breaking trend functions in macroeconomic variables. Journal of econometrics, 80(2), 355-385.

Pesaran, M., Shin, Y. (1999). An autoregressive distributed lag modeling approach to Cointegration analysis. In: Strom, S. (Ed.), Econometrics and Economic Theory in the 20th Century: The Ragnar Frisch centennial Symposium. Cambridge University Press, Cambridge, UK.

Pesaran, M., Shin, Y., Smith, R. (2001). Bounds testing approaches to the analysis of level relationships. Journal of Applied Econometrics, 16, 289-326.

Phillips, P. C. (1987). Time series regression with a unit root. Econometrica: Journal of the Econometric Society, 55(2),277-301.

Plümper, T., \& Troeger, V. E. (2007). Efficient estimation of time-invariant and rarely changing variables in finite sample panel analyses with unit fixed effects. Political Analysis, 15(2), 124-139.

Radelet, S. (2006). A primer on foreign aid. Center for Global Development working paper, no. 92. Washington, DC: CGD.

Reed, H. E., \& Mberu, B. U. (2014). Capitalizing on Nigeria's demographic dividend: reaping the benefits and diminishing the burdens. African population studies, 27(2), 319-330.

Saggi, K. (2002). Trade, foreign direct investment, and international technology transfer: A survey. The World Bank Research Observer, 17(2), 191-235.

Samargandi, N., Fidrmuc, J., \& Ghosh, S. (2015). Is the Relationship Between Financial Development and Economic Growth Monotonic? Evidence from a Sample of MiddleIncome Countries. World Development, 68, 66-81. 
Stern, D. I. (2004). The rise and fall of the environmental Kuznets curve. World development, 32(8), 1419-1439.

Stock, J. H., \& Watson, M. W. (1993). A simple estimator of co integrating vectors in higher order integrated systems. Econometrica: Journal of the Econometric Society, 783820.

Thomas, H. C. (2006). Trade Reforms and Food Security: country case studies and synthesis. Food \& Agriculture Organisation of united nations, Rome.

Trading Economics. (2018). Nigeria Rural population. Trading Economics. https://tradingeconomics.com/nigeria/rural-population-percent-of-total-populationwb-data.html. Accessed $13^{\text {th }}$ December 2018.

United Nations Development Programme (UNDP). (2012, June 4). Country Report to the Rio+20 sumit, June 2012. United Nations Development Programme. Retrieved January $\quad 06$, 2016, from http://www.ng.undp.org/content/nigeria/en/home/ourwork/environmentandenergy/ov erview.html.

U.S. Department of State. (n.d.). 1994 Country Reports on Economic Practice and TradeReports:Nigeria. Retrieved January 06, 2017, from http://dosfan.lib.uic.edu/ERC/economics/trade_reports/1994/Nigeria.html

US Energy Information Administration. (2018). International Energy Statistics [online]. Retrieved December $\quad 29, \quad 2015 \quad$ from http://www.eia.gov/cfapps/ipdbproject/IEDIndex3.cfm

Wang, D., \& Tomek, W. G. (2007). Commodity prices and unit root tests.American Journal of Agricultural Economics, 89(4), 873-889.

Welsch, H., \& Ochsen, C. (2005). The determinants of aggregate energy use in West Germany: factor substitution, technological change, and trade.Energy Economics, 27(1), 93-111.

Wing, I. S. (2008). Explaining the declining energy intensity of the US economy. Resource and Energy Economics, 30(1), 21-49.

World Bank (2001). World Development Report 2000/2001. The World Bank, Washington, DC.

The World Bank (2017). World development indicators 2018. World Bank online databank. The data are available at http://data.worldbank.org/country/nigeria

World Bank group (2018). World development indicators 2018. World Bank online databank. The data are available at http://data.worldbank.org/indicator

World Bank. (2008). International Trade and Climate Change: Economic, Legal and Institutional Perspectives. Washington, DC: World Bank.

Zha, D., Zhou, D., \& Ding, N. (2009). The contribution degree of sub-sectors to structure effect and intensity effects on industry energy intensity in China from 1993 to 2003. Renewable and Sustainable Energy Reviews, 13(4), 895-902.

Zivot, E., \& Andrews, D. W. (1992). Further Evidence on the Great Crash, the Oil-Price Shock, and the Unit-Root. Journal of Business \& Economic Statistics, 10(3), 251270. 


\section{Appendix A}

Figure A1: Annual growth rate of industry value added in Nigeria, 1981-2015

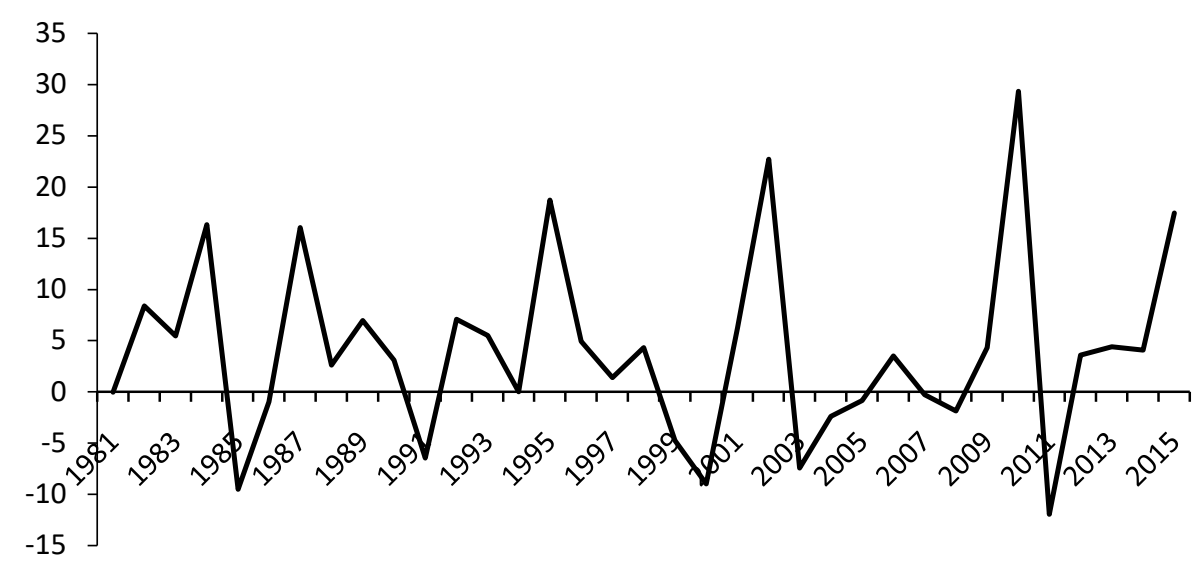

\section{Appendix B}

\section{Figure B1: Plots for energy intensity Equation}

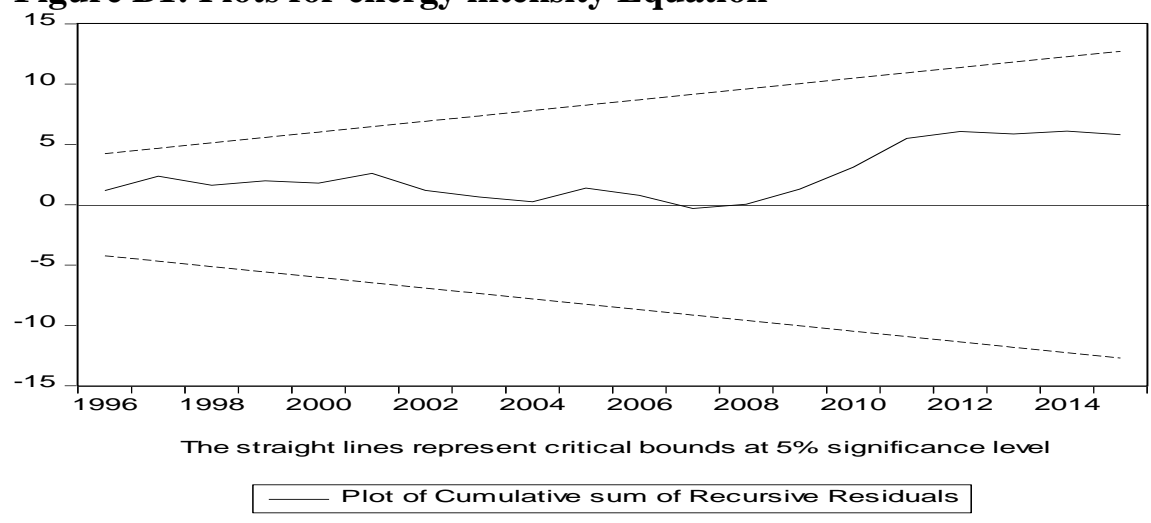

Plot of Cumulative sum of Squares of Recursive Residuals. The straight lines represent critical bounds at $5 \%$ significance level

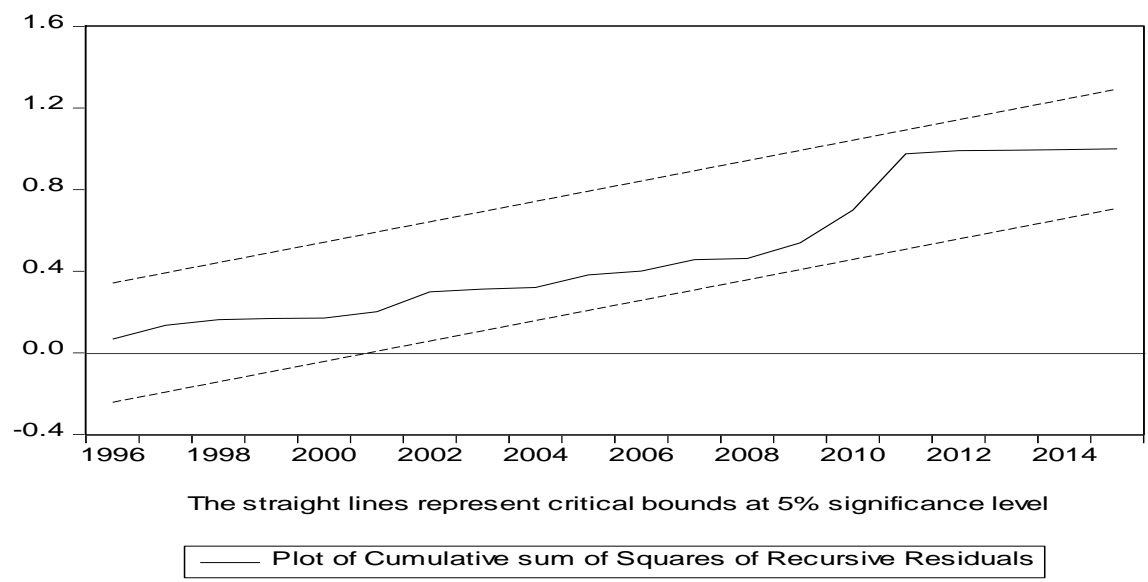

